Chapter submission (Switzerland) "Book Project "Local Migration Policy"

Author information

Name: Kurt Stefanie

Professional title: Assistant Professor (Tenure Track), Dr. iur.

University/Department: University of Applied Sciences and Arts Western Switzerland, HES-

SO VS, School of Social Work, Sierre/Siders

Email address: stefanie.kurt@hevs.ch

Tel: 0041276069100

Country: Switzerland

Short description: Stefanie Kurt is an Assistant professor at the school of Social Work at the University of Applied Sciences and Arts Western Switzerland and IP-Leader in the Swiss National Center of Competence in Research NCCR — on the move. She holds a Master of Law degree in International and European Law from the University of Bern and a PhD in Law from the University of Neuchâtel. In her research and publications, she discusses questions of Migration Law and Policy, with a particular to Citizenship and integration policies in Switzerland and Europe.

Name: D'Amato Gianni

Professional title: Prof., Dr. pol.

University/Department: University of Neuchâtel, Swiss Forum for Migration and Population Studies

Email address: gianni.damato@unine.ch

Tel: 0041327183930

Country: Switzerland

Short description: Gianni D'Amato is Professor at the University of Neuchâtel, Director of the Swiss National Center of Competence in Research NCCR - on the move and Head of the Swiss Forum of Migration and Population Studies (SFM). His research interests focus on citizenship, mobilities, populism and the history of migration. 


\title{
The Swiss Rationale of Integration Policies: Balancing Federalism, Consociationalism and Direct Democracy
}

\begin{abstract}
The following chapter summaries from an historical perspective recent developments of Swiss migration policy with a particular focus to the challenges given by the federal system and direct democracy on the local level of integration policy. It starts with a comprehensive historical summary on the rationales of immigration to Switzerland and continues with an institutional analysis of Swiss migration policies, setting the focus on federalism, consociationalism and direct democracy, and the consequences for the local actors. The authors highlight examples of current local initiatives, due to the absence of in-depths studies on the effectiveness and the impact of these policies on the local level. Thus, it follows a short overview based on the first study on migration and public opinion on migrants. Finally, the article concludes with remarks on the current integration framework with a particular emphasis on the cantonal and municipal actors, suggesting more studies to be done in the future with regard to local integration policies.
\end{abstract}

\section{Keywords}

Switzerland, Federalism, Direct Democracy, Consociationalism, Cantons 


\section{Introduction}

Switzerland $^{1}$, a non-European Union member, is a federal state that experienced since decades an intense political debate on the rationale of integration. Its integration policy, marked by the federal level, 26 cantons, 2222 political municipalities and various social actors, as well challenged by consociationalism and direct democracy, changed - as in other European countries - its paradigm in recent years. Swiss integration policies, influenced strongly by labour market demands, is outlined today within the Federal Act on Foreign Nationals and Integration (FNIA). This legal framework with its principles and rules sets integration priorities mainly in regular structures such as school, work places and health institutions. Complementary, the Cantonal Integration Programs (CIP) adds specific integration measures in three different pillars and the Integration Agenda targets even more specifically person undergoing the asylum procedure, such as refugees and temporarily admitted persons. This established practice is the outcome of different particular institutional settings, such as consociationalism in Swiss politics as much as the expression of direct democratic popular (veto-)power through xenophobic movements. Moreover, though the federal level has the competence to frame integration policies, the local level is also involved in this process and can include its opinion due to the multilayered consociational political system.

Accordingly, art. 53 para. 1 FNIA states that not only the federal and the cantonal level, but also the local level has to take integration and the protection against discrimination into account in fulfilling their functions. Consequently, local actors share a large responsibility in implementing Swiss integration policy. In particular, the local level "shall create favourable regulatory conditions for equal opportunities and for the participation of the foreign population in public life" (Art. 53 para. 2 FNIA). At present, studies on the effectiveness and outcome of (federal) integration policies at the local level are not yet available. However, different cantonal comparative studies reveal consistent differences between cantons not only in applying federal legislation but also concerning the rationale of the integration policy. Anyhow, examples of current local integration initiatives determine the scope of action within a federal framework.

\footnotetext{
${ }^{1}$ The article was supported by the National Centre of Competence in Research (NCCR) - on the move, which is funded by the Swiss National Science Foundation.
} 
Thus, this chapter offers a short introduction in the Swiss immigration rationale displaying remote and more recent developments. It mentions three important shifts of the integration rationale in Swiss history. The second part analyses institutional aspects of Swiss migration policies, such as federalism, consociationalism, direct democracy and the consequences for municipalities. Accordingly, it confronts the results with the effectiveness and impacts of Swiss integration policy at local level in spite of the absence of specific research studies, followed by a short overview about current data on public opinion. Some reflexive remarks are presented at the end of the chapter.

\section{Rationale of Immigration to Switzerland: a short introduction from a historical perspective towards recent developments}

From the Second World War until the late 1990s, the labour market demands influenced Switzerland's admission policy and subsequently the integration rationale. Admission policies focused on the principle of labour rotation that targeted the need of the economy, and not on integration instruments or integration programs for migrants. Thus, Switzerland did not consider labour market migrants as a potential part of the population. A first shift to a more inclusive migrant integration policy started in the 1970s, as the migrant's stays lengthened and their attitudes and expectations started to influence the rationale of the admission policy. Nevertheless, actors who supported a more inclusive legislation reform, concretely the federal government, as much as regional economic interests and human rights were continuously opposed by a strong xenophobic movement. This movement influenced the decision-making process through constitutional initiatives and the implicit threat to take a referendum against liberal legal reforms. This policy was consistent with the Swiss minimal welfare state, as Switzerland excluded migrants from access to social services and benefits until the 1970s (D’Amato 2012, Niederberger 2004, Campisi 2014). Influenced by the oil crisis in the 1970s, a next paradigm shift changed the rationale since the State realized that migrants, who were working in Switzerland and not returning home, would stay, start a family and have children. This awareness lead to several important legal changes, such as the introduction of an unemployment insurance, the inauguration of a larger welfare system, including protecting migrants and the possibility for family reunification. Thus, labour migrants received access to social citizenship. In parallel, "unwanted" non-economic migration increased in Switzerland, letting the asylum sector emerge. The Swiss government reacted with a two-tiered approach as it introduced a new severity approach on asylum and a deterrent policy with regard to 
irregular immigration, but determining also integration measures for the desired labour migrants, although this later policy was negligible at the beginning (D'Amato 2012, Niederberger 2004, Campisi 2014).

A second important shift in Swiss integration policy rationale started with the entry into force of the total revised National Foreigners Act (FNA) in 2008. One of the most important issues during the political and societal debates on the FNA was whether integration should be a State's responsibility to be promoted and required or whether it would be the duty and responsibility of immigrants to integrate into Swiss society at their own expense. Between these two dissimilar understandings of the future integration policy, the Parliament finally found a consensus. On the one hand, the State should provide integration instruments; on the other hand, migrants shall contribute to her/his own integration into Switzerland. This core principle of 'promoting and requiring' (encourager et exiger; Fördern und Fordern) of integration (art. 4 FNIA) is still today shaping the Swiss discourse on integration. Additionally, according to this legal framework integration starts (only) with a secure legal status. Thus, only migrants with a valid legal residence permit have access to integration programs and/or to specific integration measures (Kurt 2017a). Only a year later, in 2009, the Tripartite Conference, a political platform in which the federal, cantonal and municipal level coordinate their efforts, presented a report on the future development of the Swiss integration policy (TAK 2009). The Tripartite Conference demanded, among other measures, a stronger legal regulation of integration measures. The Federal Council responded suggesting the implementation of cantonal integration policies that could benefit of federal financial support. Moreover, the Federal Government recommended to revise the current integration regulations in the FNA as well as to strengthen the protection against discrimination (Report Schiesser 2010). Soon afterwards, Cantonal Integration Programs were initiated (CIP; started in 2014 and prolonged until 2021), with its legal provisions embedded in the partially revised FNA. Currently, every canton has its own Cantonal Integration Program based on three pillars, "Information and counselling", "Education and employment" and "Mutual understanding and social integration".

The third and last important shift towards a Swiss rationale on immigration was the favourable vote on the popular initiative 'Against Mass Immigration' balloted 9 February 2014 and promoted by a major populist party. The article stipulates that the ability to integrate should be a decisive criterion for granting residence permit (art. 121a para. 3 Swiss 
Constitution). For the first time an article of the Swiss constitution mentions the term integration in connection with migration issues. This voting influenced also the on-going partial revision of the FNA. Finally, the outcome of this process was a new law, the Federal Act on Foreign Nationals and Integration (FNIA), which entered into force $1^{\text {st }}$ January 2019. It implements the so-called integration stage model, which promotes the incremental upgrading of one's legal status in combination with integration exams (Kurt 2017, Kurt 2017a). Recently, the Swiss Confederation and the cantons decided to implement, embedded in the already existing Cantonal Integration Programs, a supplementary Integration Agenda. Switzerland intends to strengthen and harmonize integration measures for refugees and temporary admitted persons and to synchronize it with the acceleration of the asylum procedure. The restructuration and acceleration of the asylum procedure is the outcome of a longer political process, influenced in 2011 by the increasing asylum claims and finally implemented in March 2019. However, as asylum claims decreased (from 39'523 in 2015 to $18^{\prime} 088$ in 2017) and due to the acceleration of the asylum procedure, the focus is currently set more on labour market integration of asylum claimants who have a high probability to remain in the country, though they may have different legal status (Integrationsagenda Schweiz 2018). Additionally, NGO engagement may gain more importance, since the restructuration and acceleration of the asylum procedure opens to them a new field of action in implementing integration measures to formerly excluded groups (Efionayi-Mäder, Truong and D'Amato 2015). Nevertheless, specific research on this topic is missing, particularly at local level.

\section{Institutional analysis of the Swiss Migration Policies: Federalism, Consociationalism,}

\section{Direct Democracy and the consequences for municipal autonomy}

Swiss institutional structures, notably federalism, consociationalism and direct democracy, constitute a framework in which many actors and stakeholders attempt to influence the decision-making process and consequently shaping the integration policy of migrants. Subsequently, political system of this sort challenge local authorities since they are not only involved in the decision-making process, but also addressed to implement the previously negotiated integration policy and integration agenda.

\subsection{Federalism}

As a federal state, Switzerland is confronted with the challenges of multi-level governance. Certain centralizing mechanisms, which in Germany and the US are enforced by the Supreme 
Court, are less successful in Switzerland. Centralizing legal approaches are counteracted by Parliament and the people. As Wolf Linder has stated, one important limitation of the central government institutions in Switzerland is the limited possibilities for coercive implementation of federal policies (Linder 1998:22). In this sense, federal political authorities are often compelled to induce cooperation with the cantons by offering financial subsidies (e.g. Cantonal Integration Programs and the Integration Agenda). This federal structure may have an advantage, since knowledge of local interests can lead to quicker, more appropriate decisions, ensuring greater recognition of particular interests (e.g. minorities). While the Federation has the legislative power in most areas, responsibility for implementing federal policies resides largely with the cantons. For the Federation, this has the advantage of reducing its workload; for the cantons, the advantage lies in controlling their own program priorities and being able to adapt federal policies to local contexts. These aspects of the Swiss federal state also affect integration policies. In this case, the central actors are the cantons and the municipalities. In particular, cantons have room for manoeuvre when it comes to the promotion and implementation of integration provisions as recommended by federal institutions. In many cantons, the Cantonal Offices for Migration are the actors who decide how the law is interpreted and implemented regarding to integration aspects connected to a legal status. Additionally, integration offices develop measures intended to help migrants to integrate in areas such as education, work places and institution of health in the regular structure of integration. In terms of implementation, this executive federalism is decisive: it is one of the cornerstones of the Swiss political system. Although the legislative authority lies with the federal government, its implementation is entrusted to the cantons. For the cantons to fulfil this role, they need a margin of appreciation in the application of federal laws. This allows the adaptation of the implementations to local conditions, which leads to a higher legitimacy of the decisions. This is the case for the Cantonal Integration Programs (CIP) and the newly adopted Integration Agenda, which provide both sufficient material and conceptual resources, which would otherwise not be locally available.

Other characteristics of the Swiss political system are direct democracy and consociationalism, which above all favour strong organizations that can win a referendum. These peculiarities have consequences for the design of migration policy in Switzerland (see in detail Cattacin and Kaya 2005): there is a risk that federalist regulations at the cantonal 
level will foster a patchwork of measures that are exposed to the continuous populist instrumentalization.

\subsection{Consociationalism and direct democracy}

Consociationalism and direct democracy are important for understanding Switzerland's outcome and output in integration policies. But, as Mahnig and Wimmer (2003) stated in their lucid article, these two characteristics of the Swiss political system are responsible for the country's intense politicization of migration issues and the exclusion of migrants from political participation. Consociationalism includes reaching compromise between political forces that goes beyond the search for simple majorities (Linder 1998). A permanent process of compromise building between these groups characterizes Swiss politics. Another important means to influence the political decision-making process is the consultation procedure, the phase in legislative preparation when draft bills by the Confederation are evaluated by the cantons, parties, associations and sometimes by other interested circles throughout Switzerland, in order to ascertain the likelihood of their acceptance and implementation. Persons not invited to take part in the consultation procedure can also state their views on a proposal. All views and possible objections are evaluated with a view to the veto power of those who reject a reform by means of a referendum. The Federal Government then passes the main points of its proposal on to Parliament and debates the draft bill in light of the outcomes of this consultation.

Direct democracy gives social groups some opportunities to participate directly in the political process through the aforementioned popular initiative and referendum. These are in place at the federal as well as local levels. According to some observers, it is the instruments of direct democracy that allowed the consociational system to emerge, because all laws voted in Parliament can be submitted to a referendum and therefore need the support of large alliances within the political elite (Neidhart 1970). These two main characteristics of the political system provoke major politicization of the migrant issue and the exclusion of immigrants from the political participation. Since the interests in the political field of migration are too divergent, it is difficult for the parties to come to an agreement easily. Second, the instruments of direct democracy have forced the political elite to negotiate anti-immigration attitudes with populist challengers. Immigration policies that had permitted the various actors to agree to accommodate the economic needs of the country became one of the most contested and 
controversial issues since the 1960 s, when radical right-wing populist parties started to gain public support claiming that Switzerland was becoming 'over-foreignised' by ever-increasing immigrants. Using the tools of direct democracy, these xenophobic movements succeeded in vetoing liberal government reforms and put their parties under pressure through the launching of eleven popular initiatives and several referendums to curb the presence of foreigners. Although until the minaret initiative 2009 none of these initiatives passed, they have already since the 1970s consistently influenced the migration policy agenda and possibly public opinion on immigration issues urging the Swiss government to adopt more restrictive admission policies (Niederberger 2004), as manifested recently with the approval of the "mass immigration initiative" in 2014. Other European countries may be able to adopt policies 'behind closed doors' (Guiraudon 2000) to extend political and social rights to migrants, but this is nearly impossible in Switzerland.

\section{Effectiveness and Impacts of the Swiss integration policy on the local level}

So far, there are no in-depth studies regarding the effectiveness and impacts on the local municipality level regarding the integration policy in Switzerland. Although the Swiss federal structure and its legislation helps to promote and harmonize the implementation of cantonal legislation through its Cantonal Integration Program, the integration policy is framed ultimately at the local level (see Bader and ali. 2011). Nevertheless, a study from 2011 underlines the importance of cantonal differences in applying the legal framework on integration (Wichmann and ali. 2011), and a second study emphasizes the more restrictive approach of German and Italian speaking cantons compared to the French ones when it comes to integration policies (Manatschal 2013; 2011). Consequently, both results illustrate how integration and integration policy may be interpreted and implemented differently at sub-state level within a federal framework. Finally, the variation of implementation and the different cantonal priorities in executing integration policies has been confirmed by a recent evaluation of the Cantonal Integration Programs 2014-2017 (SEM 2016).

Local integration policies dates back to the 1990, but were first recognized at the federal level through enacting an ordinance on integration in 1999 (D'Amato and ali. 2012). One of the rare studies on the effectiveness of local integration policies, published in 2011 and referring to the canton of Berne, comes to the conclusion that different factors mark the intensity of communal integration policies. Local differences within the same canton are due to the 
institutional setting: some municipalities have the capacity to start with a structured organization, establishing concepts and need assessments, and providing the necessary financial resources, while other municipalities are reacting ad-hoc, responding pragmatically only in the case of need. Regarding the content of those integration policies, the municipalities in the canton of Berne have more commonalities than differences. Therefore, the federal and cantonal level, including their financial contributions, exercise more influence in shaping the content of local integration policies than the composition of the migrant population (Bader and ali. 2011).

\subsection{Examples of recent local initiatives: Encouraging access to citizenship}

In the past years, different cantonal or local actors implemented different initiative around the encouragement to access Swiss citizenship. A recent example of a cantonal initiative is the active promotion of naturalization in the canton of Geneva. Due to the federal changes in the Swiss Citizenship Act and its more restrictive conditions, the government of Geneva decided to stimulate the application of those migrants who fulfil the legal criteria for naturalization. Other cantons (e.g. Vaud) and cities (e.g. Zurich) adopted the encouragement policy of Geneva.

Cantons are not the only actors. Due to the margin of appreciation, local authorities have the possibility to implement integration policies, too. One of the recent examples is Berne's introduction of Urban Citizenship in its integration guidelines. The city of Berne announced to examine - together with civil society associations (in particular the association for sanspapiers) - the introduction and implementation of a City-Card in its new integration rules. According to this provision, all persons living in the city of Berne may become a City-Card holder able to prove their identity, regardless of their legal status. The aim has been to label the city as "migrant-friendly" and to establish a "welcome-culture" for all new residents of Berne (Stadt Bern 2018).

These few examples illustrate the complexity of the Swiss integration rationale. To conclude, some integration policies result from a bottom-up, others from top-down approach. Even if the majority of provisions regarding integration policies is framed by the federal level, the mix of these different approaches enables the cantonal and municipal level to adopt specific measures and adapt it to its needs. But future political developments or legal changes are 
difficult to be anticipated due to the complex system that balances direct democracy, federalism and consociationalism.

\subsection{Actual data on migration and public opinion on migrants}

The Federal Statistical Office published 2017 a study on diversity and coexistence in Switzerland. It is one of the first public opinion studies that give large insights on how migration and multicultural coexistence is perceived by different parts of the population. In Switzerland, inhabited by more than 190 different nationalities and more than 10 different religious communities, $36 \%$ of the population answered that they feel bothered by individuals identified as "other and different". However, in the majority of cases the population is tolerant and in favour to grant more rights to the migrant population. Subsequently, $56 \%$ of the interviewed persons in the poll state that integration of migrants' works well. Nevertheless, $66 \%$ recognize racism as a key social problem. However, the majority is convinced that integration measures and prevention policies operated against racism are useful. However, 29$34 \%$ of the interviewed persons are unsatisfied or unhappy with the implemented framework and favour either more or less measures (FSO 2017).

\subsection{Conclusion}

Switzerland has had in the past an intense political and societal debate on integration policy. The different developments as well as direct democracy, federalism and consociationalism mark the Swiss integration rationale until today. Due to its multi-level system of governance, local and even more so cantonal actors are involved in establishing and in implementing the pillars of Swiss integration policy. Additionally, since the introduction of the Cantonal Integration Program in 2014 and the newly Integration Agenda Switzerland in 2018, Switzerland has institutionalized and to certain extent harmonized its integration policy. Thus, all cantons and municipalities have implemented a structure that promotes integration. However, the institutional framework still admits openness towards new initiatives, and is able to target the specific needs of cantons and municipalities. Subsequently, in-depth studies on local integration policies that address good practices and innovative forms are still to be done. It would help to gain a deeper understanding on the true outcome of these policies, namely there where people actually live.

\section{References}


Bader, D., Pecoraro M., Schönenberger S., Wichmann N. (2011). Integration im Kanton Bern - Migrationsbevölkerung und Integrationsförderung im Fokus, Rapport SFM. Neuchâtel.

Bundesrat (Federal Council). (2011). Bericht zur Weiterentwicklung der Integrationspolitik des Bundes. Bern.

Campisi, L. (2014). Die rechtliche Erfassung der Integration im schweizerischen

Migrationsrecht, Zwischen rechtlichen Vorgaben und innenpolitischen Realitäten. Zurich, St. Gallen: Dike.

Cattacin, S., Kaya, B. (2005). Le développement des mesures d'intégration de la population migrante sur le plan local en Suisse. In: H. Mahnig (Ed.), Histoire de la politique de migration, d'asile et d'intégration en Suisse depuis 1948 (p. 288-320). Zurich: Seismo.

Cattacin, S., Chimienti, M. (2009). Lokale Politik der Eingliederung der Migrationsbevölkerung in der Schweiz - Zwischen Pragmatismus und Populismus. In: Gesemann, F., Roth, R. (Eds.). Lokale Integrationspolitik in der Einwanderungsgesellschaft (p. 655-671). Wiesbaden: Springer.

D’Amato, G., Suter, C. (2012). Monitoring immigrant integration in Switzerland. In: R. Bij1 \& A. Verweij (Eds.), Measuring and monitoring immigrant integration in Europe: integration policies and monitoring efforts in 17 European countries (pp. 326-343). The Hague: The Netherlands Institute for Social Research/SCP.

D’Amato, G. (2012). Switzerland. In: Christian Joppke and Leslie Seidle (eds.): Immigrant Integration in Federal Countries (p. 162-191). Montreal: McGill Queens University Press

D'Amato, G., Gerber, B. (eds). (2005). Herausforderung Integration:

städtische Migrationspolitik in der Schweiz und in Europa. Zürich: Seismo.

Efionayi-Mäder D., Truong J., D’Amato G. (2015), “Wir können uns ein Abseitstehen der Zivilgesellschaft nicht leisten.” Zivilgesellschaftliches Engagement im Flüchtlingswesen, Rapport SFM. Neuchâtel.

Eidgenössisches Justiz- und Polizeidepartement, Integrationsagenda Schweiz, Bericht der Koordinationsgruppe vom 1. März 2018. Bern. 
Guiraudon, V., (2000). Les politiques d'immigration en Europe: Allemagne, France, PaysBas. Paris: L'Harmattan.

Kurt, S., (2017). Fast-Tracking Full Citizenship in the Context of the Swiss Integration Stage Model, NCCR on the Move Working Paper \#15: Neuchâtel.

Kurt, S., (2017a). A modest Start: Integration Policies in the Field of Asylum, in: Highlights \#2, E-Magazine NCCR on the move: Neuchâtel.

Linder, W., (1998). Swiss democracy: possible solutions to conflict in multicultural societies. Houndmills: Macmillan.

Mahnig, H., Wimmer A., (2003). Integration without immigrant policy: the case of Switzerland, in Friedrich Heckmann \& Dominique Schnapper (eds.), The integration of immigrants in European societies: national differences and trends of convergence (p. 135164). Stuttgart: Lucius \& Lucius.

Manatschal, A., (2013). Kantonale Integrationspolitik im Vergleich. Eine Untersuchung der Determinanten und Auswirkungen subnationaler Politikvielfalt. Baden-Baden: Nomos.

Manatschal, A., (2011). Taking Cantonal Variations of Integration Policy Seriously - or How to Validate International Concepts at the Subnational Comparative Level, Swiss Political Science Review 17(3): 336-357. https://doi.org/10.1111/j.1662-6370.2011.02027.x

Neidhart, L., (1970), Plebiszit und pluralitäre Demokratie. Eine Analyse der Funktion des schweizerischen Gesetzesreferendums. Bern: Francke.

Niederberger, M., (2004). Ausgrenzen, assimilieren, integrieren: die Entwicklung einer schweizerischen Integrationspolitik. Zürich: Seismo.

Niederberger, M., in Zusammenarbeit mit Sandro Cattacin (2002). Migrationspolitik in Agglomerationen. Eine explorative Analyse der zentralen Problem- und Interventionsfelder in der Schweiz, Forschungsbericht, Studie im Auftrag der Tripartiten Agglomerationskonferenz - TAK: Neuchâtel.

Niederberger, M., (2004). Ausgrenzen, Assimilieren, Integrieren: die Entwicklung einer schweizerischen Integrationspolitik. Zürich: Seismo. 
Staatssekretariat für Migration (2016). Jahres- und Zwischenberichte der kantonalen Integrationsprogramme KIP. Bern.

Stadt Bern, Schwerpunktplan 2018-2021 zur Umsetzung des Leitbildes zur Integrationspolitik, 2018.

Swiss Federal Statistical Office (FSO), Press release, Initial findings from the survey on diversity and coexistence in Switzerland 2016, 10.10.2017.

Tripartite Agglomerationskonferenz (TAK) (2009). Weiterentwicklung der schweizerischen Integrationspolitik, Bericht und Empfehlungen der TAK vom 29. Juni 2009. Bern.

Wichmann, N., D'Amato G., (2010). Migration und Integration in Basel-Stadt: ein "Pionierkanton" unter der Lupe. Forum suisse pour l'étude des migrations et de la population (SFM): Neuchâtel.

Wichmann, N., Hermann, M., D’Amato, G., Efionayi-Mäder D., Fibbi, R., Menet, J., Ruedin, D. (2011). Gestaltungsspielräume im Föderalismus: Die Migrationspolitik in den Kantonen: Bern: EKM. 